\title{
HEGESZTÉS HŐTERJEDÉSÉNEK MODELLEZÉSE ÉS VALIDÁLÁSA TOMPA VARRAT ESETÉN
}

\section{HEAT TRANSFER MODELLISATION AND VALIDATION IN CASE OF BUTT VELDING JOINT}

\author{
Halász Gergely ${ }^{1}$, Kuti János ${ }^{2}$, Széll Károly ${ }^{3}$ \\ 1,2 Óbudai Egyetem Bánki Donát Gépész és Biztonságtechnikai Mérnöki Kar Anyag- \\ technológiai Intézeti Tanszék, 1084 Budapest, Népszínház u. 8.; +36-1-666-5386, \\ gerryhalasz@gmail.com, kuti.janos@bgk.uni-obuda.hu \\ 3 Óbudai Egyetem Alba Regia Müszaki Kar, Mérnöki Intézet, 8000, Magyarország, \\ Székesfehérvár, Budai út 45. K/37; +36 (22) 200-499, szell.karoly@amk.uni- \\ obuda.hu
}

\begin{abstract}
Aim of our work to compare the results of the virtual model with the measured heat transfer data. The primary goal to compare the real time measured with the program simulated data. The copy of the virtual model is the real product (like a prototyping process this sample also exists). Before beginning of any production process this model is tested and experimented under loads. One of the testing procedures is the joining. In case of many parts the joining process is a key technology, it needs to know the welding heat effect for the microstructure in the heat affected zone and the joint.
\end{abstract}

Keywords: welding, heat affected zone, heat transfer, model validation.

\section{Összefoglalás}

Kutatásunk célja, hogy összehasonlítsuk a virtuális modellben kapott szimulált értékeket a valódi, hegesztés közben mért hőterjedési értékekkel. Elsődleges cél, az egyes időpillanatokban mért hőmérsékleti értékek összehasonlítása a programban szimulált értékekkel. A virtuális modell pontos mása a készterméknek (akárcsak a prototípus, csak ez valójában nem létezik). Még mielött bármit gyártanának, előtte ezt a virtuális modellt vizsgálják, tesztelik és igénybevételeknek teszik ki. Ezen modellek vizsgálatának egy fontos részét képezi a kötéstechnológia. Sok alkatrész elkészítésénél kulcsfontosságú a hegesztés, és tudnunk kell, hogy ez milyen hatásokkal jár az alapanyagunk belső szerkezetében, a hőhatásövezetben és a kialakuló varratban.

Kulcsszavak: hegesztés, modell, höterjedés, modell validálás.

\section{Hőterjedés}

Ha valamely testnek és környezetének a hőmérséklete különbözö, közöttük hőcsere indul meg és a hömérsékletük idővel kiegyenlítődik. A hőátadási együttható a tárgy és a környezete között az az időegységen- ként és felületegységenként kicserélődő hőmennyiség, amely a felületre merőlegesen belép a testbe, vagy abból kilép. Ez a hőcsere hővezetéssel, hőáramlással és hősugárzással megy végbe. 


\subsection{Hővezetés}

Hővezetés során a hőcsere a szomszédos, nyugalomban lévő részecskék között megy végbe, tehát a szilárd testekre jellemző. Folyadékban vagy gázban akkor terjed a hö vezetéssel, ha az anyag részecskéi nyugalomban vannak. A fémek hővezető képessége függ:

- az összetételtől,

- a szerkezeti állapottól,

- a hőmérséklettől.

\section{Hőmérő eszközök}

A hegesztések alatt a hőmérsékletek validálásához szükségünk volt hőmérő eszközökre, amelyek segítségével egy adott pontban mérni tudtuk a hőmérsékletet. A kísérletekhez három hőmérsékletmérési módszert vettünk fontolóra: a hőkamerát, a termoelemet és az infrahőmérőt. Ezek közül számunkra a termoelem volt az optimális.

\section{Kísérleti munkadarabok előké- szítése}

Az alapanyag S355 anyagminőségü, hidegen hengerelt általános rendeltetésű szerkezeti acél. A próbadarabokat Messer Hungarogáz Kft. biztosította. A lemezek mérete 8x100x250mm. A próbatestek méretre vágva és leélezve érkeztek meg az egyetemi hegesztőlaborba. A leélezés minden darab esetében $15^{\circ}$-os, az előkészítés összesen $30^{\circ}$. 4 előkészített lemezbe a leélezett peremtől 20mm-re, a varrattal párhuzamosan 5 darab egyenként $6 \mathrm{~mm}$ mély és $1,7 \mathrm{~mm}$ átmérőjü zsákfuratokat fúrtunk egymástól 40mm távolságra.

Ezek a furatok biztosítják, hogy a termoelemek metszetben helyes hőmérsékleti értékeket adjanak. A furatok távolsága az összes darabnál egységes: a varrattól $20 \mathrm{~mm}$, a szélétől és egymástól $40 \mathrm{~mm}$.

\section{Hegesztési eljárás}

A kísérleti hegesztéseket az egyetem ívhegesztő laboratóriumában végeztük el. Az egyszerübb kivitelezés kedvéért egy lineáris hegesztőgép segítségével készítettük el a varratokat, így a hegesztési sebesség állandó volt, és a hegesztő személyzetből származó hibákat kiküszöböltük.. A hegesztést huzalelektródás, aktív védőgázas ívhegesztéssel, ismertebb nevén MAG (Metal Activ Gas welding) hegesztéssel végeztünk. Az alkalmazott védőgáz szabványos M21-es gáz volt (Ar+18\%CO2).

\subsection{Hegesztőgép ismertetése}

A hegesztő hibájának kiküszöbölésére lineáris hegesztőgépet alkalmaztunk. Az egyetemi hallgató által tervezett egyedi gépnek köszönhetően a hegesztést egyenletes sebességgel és huzalelőtolással tudtuk elkészíteni. A gép munkaterülete 1000x660x600mm. Segítségével biztosítva volt, hogy a sebesség, a pisztolytartás és a hegesztési áramerősség minden mérésnél megegyezzen.

\section{Kísérlet leírása}

A próbahegesztések alatt meghatároztuk a huzalelőtolás sebességének változtatásával a hegesztési áramot és az alkalmazandó hegesztési feszültséget. A megfelelö kötés kialakítását, a hegesztési áram és a feszültség kiválasztott értékei mellett a 14 cm/perc-es hegesztési sebesség biztosította. A kísérletek alatt a következő állandó paraméterekkel dolgoztunk: hegesztési sebesség: 14 cm/perc; árameröség: 180A; feszültség: $23 \mathrm{~V}$.

Az első próbatestet alátámasztás nélkül a munkapadra helyeztük, a furatokba beillesztettük az öt termoelemet, és a gép segítségével meghegesztettük. Közben figyeltük az áram és a hőmérséklet változását. A hegesztés befejezésével dokumentáltuk az elkészült varratot, és megvártuk, amíg $100^{\circ} \mathrm{C}$ alá hül a próbatest. Ezután kivettük a termoelemeket, megjelöltük a darabot, és a gyökoldalt is dokumentáltuk. A második próbatestet vékony huzallal támasztottuk 
alá a végein, hogy minél kisebb legyen a hőelvonás. Az alátámasztásból fakadó jóval kisebb höelvonás a termoelemmel mért hőmérséklet értékein is jól látszik. A hegesztés végeztével a gyökoldalt is dokumentáltuk.

A második próbatest után már nem változtattunk a kezdeti feltételeken, minden ugyanaz maradt a harmadik és negyedik mérésnél is.

A kapott alapadatok segítségével a MSC Marc Mentat programban elkészítettem a hegesztett varratot metszetben, megközelítő méretben és alakban.

\section{Modell bemutatása}

Az MSC Marc Mentat programban a hegesztett varrat megközelítő alakját modelleztük le. A hőterjedést metszetben vizsgáltuk, ezért a modell is két dimenzióban ábrázolja a varratot. A leélezést figyelembe véve készítettük el a kötést, a varrat közelében a pontokat sürün helyeztük el, hogy a lehető legpontosabb mérési eredményeket kapjuk.

A negyedik mérésnél már minden problémát ki tudtunk szürni, a hegesztőgép a méreteknek megfelelően a lehetö legjobb beállításon üzemelt.

Szélességében a modell mérete nem éri el a próbatest méreteit. Ezen probléma kiküszöbölésére mind a két oldalon hőelvonást állítottunk be, amely reprezentálja a további anyag hőelvonását. Ezután következet a modell parametrizálása. A hegesztés tulajdonságai, fluxus, anyag tulajdonságok, kezdeti és határfeltételek megadása.

\subsection{Anyagtulajdonságok}

A hőfolyamat futtatásához speciális anyagfüggvények felvételére nincs szükség, az alábbi jellemzőket használtuk:

- fajhö: $576 \mathrm{~J} / \mathrm{kg}^{\circ} \mathrm{C}$,

- anyagsürüség: $7850 \mathrm{Kg} / \mathrm{dm} 3$,

- hővezetési tényezö: $0.04 \mathrm{~W} / \mathrm{mm}^{\circ} \mathrm{C}$.

\subsection{Határfeltételek megadása}

A termikus peremfeltétel beállításához felvettünk egy pont fluxust. Mivel az elektróda és a munkadarab között az elektromos ív egy bizonyos pontban záródik, így itt keletkezik a legnagyobb hőmérséklet.

\subsection{Kiinduló feltételek megadása}

Az alapanyag hömérséklete a hegesztés megkezdése elött a környezeti hőmérséklet értékével egyezik meg.

\subsection{Igénybevételek megadása}

Itt határoztuk meg a teljes folyamat idötartamát. Mivel számunkra a hőterjedés csak a hegesztési varratra merőleges metszetben érdekes, ezért a próbatestet érő hő fluxust csak egy rövid időre kell müködtetni. Viszont a hőterjedést a teljes hegesztés alatt figyelnünk kell, mert több időbe telik még a höelvonás megtörténik.

A feltételek megadása után pedig lefuttattuk a programot. A három megadott szakasz jól láthatóan elkülönül a modell lefuttatásakor (2.ábra). Az első szakaszban, amikor az ív éppen elhalad, az ömledék hőmérséklete még olvadáspont fölött van.

A második szakaszban a hő szétterjed a darabban. A varrat és a környezete még különböző hőmérsékleten izzik. A hőhatás övezetben is megugrik a hömérséklet.

A harmadik szakaszban, - ami a leghosszabb szakasz, így itt a pontok felvétele is nagyobb idöközökkel történt - a höelvonás látható. A próbatest szépen lassan visszahül. A varrat környékén még viszonylag meleg azonban a varratól távolabb már közelít a szobahőmérséklethez.

\section{Eredmények, összefoglalás}

A mért és számított eredmények összehasonlításához mind a négy darab mérési adatait felhasználtuk, és a négy mérési pont eredményeit kiértékeltük. Ezen mérési pontokat diagramokba foglaltuk, hogy átláthatóbbak legyenek. Ezek közül itt csak egyet ismertetek (1. ábra). Összehasonlítva a 
modellben kapott eredményekkel látszik, hogy a görbék irányultsága sok hasonlóságot mutat, azonban a maximális hőmérséklet nem egyezik meg (2. ábra). Az adatok alapján megállapítható, hogy a modell nem tükrözi teljes mértékben a valóságos hegesztés eredményeit. Az eltérés igen nagy, megközelítőleg $50^{\circ} \mathrm{C}$, a maximum és a lehülési pont között. Ez valószínüleg azért van, mert a modellnél megadott hőelvonási értékek a valóságoshoz képest kisebbek.

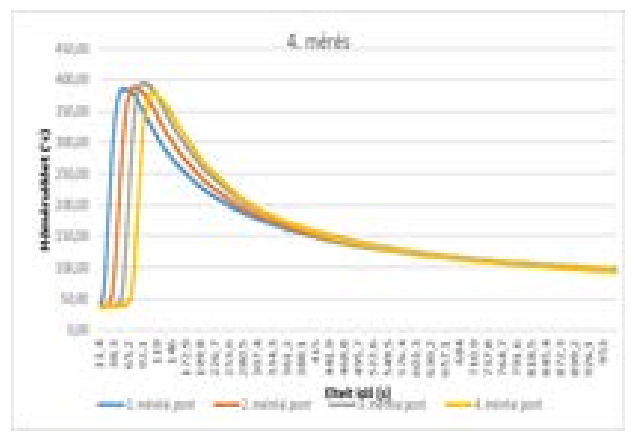

1. ábra. A termoelemekkel mért hömérsékleti értékek

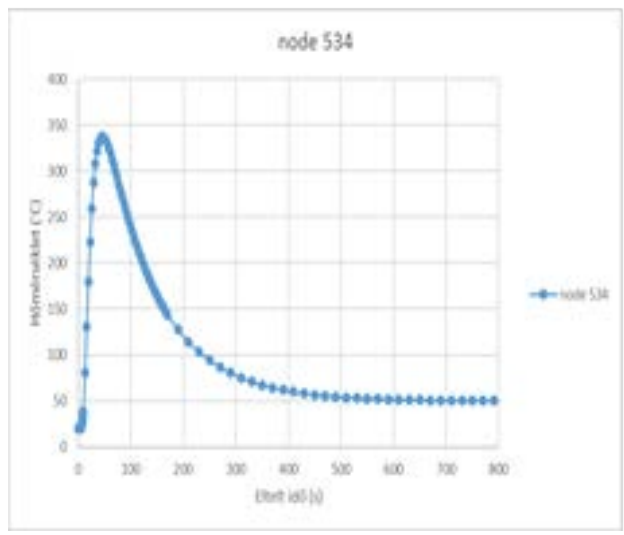

2. ábra. A modellből származtatott hömérsékleti értékek

A méretek miatt a hőelvonás értékeit nekem kellett megbecsülni, a következő szimulációnál ez a hőelvonás érték korrigálható a mért eredmények alapján, ez várhatóan közelebb hozza a szimuláció értékeit a valósághoz. Valószínübb, hogy a szoftver további beállításai sem voltak elég pontosak. A korlátozott időtartam miatt előfordulhat, hogy a modellezésnél bevitt paraméterek és az elkészült geometria hibájából fakad az eltérés. Az adatok megközelítőleg jók, de mindenképpen további vizsgálatokat igényelnek.

\section{Köszönetnyilvánítás}

A szerzők ezúton kívánnak köszönetet mondani munkánkhoz nyújtott anyagi támogatásért - az EFOP-3.6.1-16-201600010 számú projekt keretében - a Magyar Államnak és az Európai Uniónak.

\section{Szakirodalmi hivatkozások}

[1] Komócsin M.: Gépipari anyagismeret, Okom Mérnökiroda Kft., Miskolc, 1997.

[2] Szombatfalvy Á.: A hőkezelés Technológiája, Müszaki Könyvkiadó, Budapest, 1985, 9-12.

[3] Hütte: A mérnöki tudományok kézikönyve, Budapest; Berlin; Heidelberg; New York; London; Paris; Tokyo; Hong Kong; Barcelona, Springer-Verlag, 1993.

[4] Horváth Károly, Simonyi Alfréd, Zobory István: Mérnöki fizika, Müegyetemi Kiadó, Budapest, 1992.

[5] Gremsperger G., Marti S., Rejtő F.: Ívhegesztő áramforrások, Műszaki könyvkiadó, Budapest, 1987.

[6] Marc ${ }^{\circledR} 2013$ Volume A: Theory and User Information, MSC Software Corporation, 2013, 270.

[7] Csengeri Pintér Péter: Mennyiségek, mértékegységek, Müszaki Könyvkiadó, Budapest, 1987.

[8] Mikló István: Hegesztő szakmai ismeret 2., Szakmunkásképző iskolai tankönyv 2. kiadás, Müszaki Könyvkiadó, Budapest, 1991.

[9] Termoelem-hömérök, BME Energetikai Gépek és Rendszerek Tanszék, elektronikus jegyzet, ftp.energia.bme.hu/pub/Energetikai_ meresek_I/3_Termoelem-homerok.pdf

[10] Harangozó József: Hegesztett tompa- és sarokvarratok höfolyamatainak vizsgálata véges elem módszerrel, TDK dolgozat, $\mathrm{Bu}-$ dapest, 2013, 12.

[11] Tállai Kristóf Csaba: Lineáris hegesztőgép tervezés, Budapest, 2017 